\title{
The Effect of Online Communication Quality on Subjective Well-being among Entrepreneurs in Urban Area
}

\author{
Wirda Khairiyahe, ${ }^{\mathrm{a}, *}$ Bagus Takwin ${ }^{\mathrm{a}}$, Mediaty ${ }^{\mathrm{b}}$ \\ ${ }^{a}$ Faculty of Psychology, Universitas Indonesia, Depok, Indonesia \\ ${ }^{b}$ Faculty of Economic and Business, Universitas Hasanuddin, Makassar, Indonesia
}

\begin{abstract}
One of the information and communication technologies most used by the public is the use of online communication. The purpose of this study was to determine the effect of online communication quality on subjective well-being among entrepreneurs in DKI Jakarta. Data were gathered using incidental sampling techniques with an online survey. This study measures both variables with online communication quality scale (including openness, empathy, supportiveness, positiveness, and equality) and subjective well-being scale (including satisfaction with life, the scale of positive and negative experience, and flourishing scale). The sample consisted of 85 entrepreneurs who are willing to become participants, with the criteria of working, having business units (small, medium, and large) in DKI Jakarta, range age 20-40 years. This study uses the SPSS application with a quantitative research design with a linear regression analysis. The results of this study indicate that there is a significant influence of online communication quality on subjective well-being among entrepreneurs in DKI Jakarta with a significant level of $\mathrm{P}=0.016,16.7 \%$ contribution and the other $83.3 \%$ is influenced by other variables.
\end{abstract}

Keywords: quality of online communication, subjective well-being, entrepreneurs

\section{INTRODUCTION}

Covid-19 pandemic has changed the structure of human life to become completely limited by the enactment of social distancing or physical distancing. This is in accordance with Government regulation (PP) No. 21 of 2020 concerning LargeScale Social Restrictions (Peraturan Pemerintah, 2020) in the context of accelerating the handling of Corona Virus Disease 2019 (Covid-19) in Indonesia. Therefore, information and communication technology can be a solution to these situations, not only for government, but also for education, health, and business matters.

DKI Jakarta is the first province to implement PSBB in Indonesia (Mashabi, 2020). DKI Jakarta is the center of the Indonesian government, the center of business, politics, a culture so that many people come to work or earn a living. The DKI Jakarta provincial government has implemented the Jakarta Smart City program which includes Smart Governance, Smart People, Smart Living, Smart Mobility, Smart Economy, and Smart

\footnotetext{
* Author in correspondence,

Email address: wirda.khairiyah12@gmail.com (Wirda Khairiyah), bagustakwin@gmail.com (Bagus Takwin)
}

ISSN: 2549-3221 (Print) 2549-323X (Online)

DOI: $10.26487 /$ hebr.v4i1.2373
Environment. This research focuses only on two dimensions, smart people smart living. In this case, the people of DKI Jakarta are expected to become smart people who are able to use and utilize information and communication technology in positive, effective, and efficient ways. Thus, the existence of this technology is expected to create smart living to improve the standard of living, prosperity, and happiness.

One of the most common information and communication technologies used by the public is the use of the internet. Based on a survey conducted by the Indonesian Internet Service Providers Association in 2017 found that internet user penetration in Indonesia increased by $8 \%$ to 146.62 million, equivalent to $54 \%$ of the Indonesian population. Furthermore, most internet users are in urban areas with a percentage of $72.41 \%$, because in cities the infrastructure is more complete and of high quality. Based on the type of service, the most widely used service by the public is the chat application with a percentage of $89.35 \%$. Based on the time of use, the highest percentage is daily usage (65.98\%) and duration of 1-3 hours (43.89\%) The survey shows that every day most urban communities will set aside a minimum of 1-3 hours to use the internet with a chat application. In addition, in this pandemic era, the need to socialize directly with others is reduced. Therefore, urban communities utilize online communication to stay connected with friends or coworkers (Wood and Smith, 2005). 
Online communication according to DeVito (2013) is interpersonal communication that occurs through the internet and utilizes applications such as email, instant messaging, social networking sites. This research will focus on the quality of online communication of entrepreneurs, especially in urban areas because they are one of the important elements to sustain the country's economy (Efendi, 2020). In addition, entrepreneurs should also use online communication to productively build their business. Research shows that online communication is important to study because it is proven to increase work effectiveness and efficiency, human resource productivity, build good relationships between employees, marketing strategies, to the success of business units (Allameh et al. (2011); Bucăţa and Rizescu (2017); Varnali (2010)).

In the beginning, online communication was used as a medium for exchanging information with each other. However, some research results and media reports in Indonesia, state that many people who abuse the use of the internet, especially online communication, such as misunderstandings that damage friendships, cyberbullying, and even cases of sexual exploitation, hence affecting feelings of loneliness, addiction, anxiety, stress, and depression (Akin and Iskender (2011); Lestari (2018); Mustaqim (2016); Nixon (2014)). Online communication can also have a negative impact on business processes such as getting negative reviews, misinformation (system errors), being distracted for employees, so that it becomes a special pressure for employees (Akram and Kumar (2017); de Wet et al. (2016)). Regarding privacy, most Indonesian people $(90.48 \%)$ want chat applications created by Indonesians, to avoid their data being controlled, spied, or misused by foreign countries Zebua (2017). Overall, digital life can make a person behave negatively.

On the other hand, a survey of adults in America revealed that $90 \%$ of them considered that the internet had a good effect on him and $70 \%$ had a good effect on society (Smith, 2018). Because the internet makes information easier and faster to access, includes everyone connected to others, and helping them stay in closer contact with friends and family. As said by DeVito (2013) that interpersonal relationships including virtual relationships are not just connected but also related to each other, where one individual will have an impact on other individuals.

Several studies have discovered that online communication should have a good impact on one's mental health and happiness (Wheatley, 2017). Hyperconnected life changes the welfare of a person compared to the way of life before there was digital connectivity (Rainie and Anderson, 2018). Furthermore, they revealed that digital life not only makes people connected to each other, but has a deeper meaning than that, which allows people to rediscover their lives and careers, and get social support (related to academics, safety \& health).

Based on the phenomenon, it can be seen that online communication should be useful but still misused. This is important to investigate because online communication has become a part of urban life that must be used properly in order to avoid possible adverse effects. So this research assumes that the quality of online communication can make someone feel happy and achieve life satisfaction. This concept of happiness is called subjective well-being. Diener et al. (1997) define subjective well-being as an individual's assessment of his life through a cognitive assessment of life satisfaction and affective assessment of mood and emotions.

This research wants to find out how the role of information technology allows individuals to interact with one another. The purpose of this study was to determine the effect of online communication quality on subjective well-being among entrepreneurs in DKI Jakarta. Theoretically, the benefits this study are expected to add to the literature in the development of science in the field of psychology, especially related to aspects of a person's behavior (users) in using information technology (online communication), and subjective well-being. Practically, this research is expected to be an input for policymakers within the scope of the organization so that employees feel well-being at work.

\section{LITERATURE REVIEW}

\subsection{Online Communication}

Communication is basically divided into two namely direct and indirect communication (Wood and Smith, 2005). Direct communication refers to the exchange of information that is transmitted directly without intermediary media. Whereas indirect communication is a form of information exchange where there is a mediator that separates communicators through technology, such as paper, or through computer and internet devices (Wood and Smith, 2005). Both communications, direct and indirect, will form an interpersonal relationship, such as family relationships, friendship, or romance.

Online communication is related to the integration of computer technology with one's interactions in everyday life. One concept related to this is computer-mediated communication which studies how human behavior is maintained and modified by the exchange of information through machines (Wood and Smith, 2005). DeVito (2010) explains that there are five general qualities that mark effective communication, namely openness, empathy, supportiveness, positiveness, and equality. Openness means a willingness to open up and a willingness to react honestly to the messages conveyed by others. Empathy means knowing what other people experience from that person's point of view and feel like the person experiencing it. Supportiveness means showing a supportive attitude by showing descriptive, not evaluative, and provisional attitudes. Positiveness means showing a positive attitude towards yourself and others and giving positive encouragement to others, such as praise, appreciation, and so on. Equality means assuming equal when communicating.

Valkenburg and Peter (2007) explain that online communication can be known based on frequency, rate, and intensity. Frequency is related to how often individuals access the internet (online) in a week. Rate is related to how many times an individual communicates in a day. Intensity includes how long the individual conducts inline communication in a day. 


\subsection{Subjective Well-Being}

Subjective well-being is a unique experience of each individual related to positive assessments that include evaluations of all aspects of one's life (Lopez and Snyder, 2012). According to Lyubomirsky (2013), subjective well-being is an experience of joy, satisfaction, or positive well-being combined with a feeling that one's life is good, meaningful, and valuable. Some of the above meanings lead to the conclusion that subjective wellbeing is an individual's personal evaluation that is subjective about his life including through cognitive assessments in the form of assessments of life satisfaction, affective assessments in the form of assessments of positive and negative emotions, and appreciation of the meaningfulness of life seen from an assessment of the extent to which flourishing is felt. Because subjective well-being is subjective, the results will be different for everyone.

Diener et al. (1997) explained that individuals have high subjective well-being if they experience life satisfaction, often feel joy, and rarely feel unpleasant emotions such as sadness or anger. On the other hand, subjective well-being is low when we are dissatisfied with their lives, experience less joy, and affection, and more often feel negative emotions such as anger or anxiety.

Subjective well-being is divided into three components, namely satisfaction with life, emotional well-being which consists of two aspects, namely positive feelings, and negative feelings, and flourishing (Diener et al., 2009). Cognitive assessment is an individual assessment of life satisfaction, while affective assessment can be categorized into an assessment of the existence of positive effect and an assessment of the existence of a negative effect. Positive effect reflects pleasant moods and emotions such as love or affection, while negative effects such as fear, sadness, and anger. The last aspect is flourishing. Individuals who are said to be 'flourish' have good feelings so that they function effectively in their lives will ultimately be more meaningful and enjoy life's journey.

Diener et al. (1997) and Purba and Fitriana (2019) reference factors that can influence subjective well-being and mental health, namely subjective satisfaction, income, demographic factors (age, gender, race, ethnicity, work, education, religion, marriage, and family), behavior and outcomes, including social contact, a series of life events, and activities, and personality. In addition, Wheatley (2017) argues that health, technology, and time management also influence subjective well-being. Other personal characters such as optimism are associated with subjective well-being (Daukantaitė and Zukauskiene, 2012). People who are more optimistic about their future are reported to feel happier and more satisfied with their lives compared to pessimists who easily give up and despair if something happens that is not what they want it to be.

\subsection{The effect of online communication quality on subjective well-being}

In life span, a person has development tasks based on his age so that he can live his life well. The development task of early adult development (20-40 years) according to Hurlock
(1994) is to start working, have a spouse (married), manage the household, educate children, start working or have a position, bear the responsibility as a citizen, and make relationships with a particular social group that matches its values. People in early adulthood will continue to establish effective communication nor within the family, work, or social environment to accomplish the task of development. This effective communication is expected to increase one's subjective well-being. Furthermore, the relationship between internet use and subjective well-being has produced several contradictory results (Maddux (2018); Wheatley (2017)). In this case, the relationship between online communication and subjective well-being can be divided into positive or negative relationships.

A study conducted by Ishii (2017) found a significant correlation between online communication and subjective wellbeing in Japan mediated by the number of online and offline friendships held by participants. In addition, $\mathrm{Li}$ et al. (2014) found a relationship between online communication and subjective well-being from the perspective of psychological satisfaction needs, as well as the role of mediating shyness and social self-efficacy among Chinese students. Similar results have also been found in Korea, research conducted by Bae (2019) that online communication using a smartphone can increase social capital and ultimately increase subjective well-being.

Someone forms social relations through communication, including online communication. Several studies have found that social relations are one of the factors influencing subjective well-being (Hutomo, 2017). A positive relationship with others is related to subjective well-being because a positive relationship will increase social support and emotional closeness. Some psychologists even say that humans are genetically connected with needing one another.

Other research shows that online communication is associated with several social benefits, including interacting with friends and colleagues, which tends to improve well-being (Wheatley, 2017). In addition, a study shows that the larger virtual social network provides the more opportunities to develop and maintain relationships with others whereas it found to have a negative relationship with depression and anxiety (Wright et al., 2013), but have a positive relationship to satisfaction (Grieve et al., 2013). More friends and more conversations in online communication can reduce depression and anxiety and increase life satisfaction. One study showed that the more individuals who were depressed, the more negative online self-disclosure they did to attract social support from their social media friends (Park et al., 2016). Another study also found that individuals with low mental health (eg, psychological pressure or suicidal ideation) were larger users of social media (Sampasa-Kanyinga and Lewis, 2015).

On the other hand, the negative impact of online communication is loneliness and social isolation, because of increased internet use which reduces physical interaction with family and friends. Several studies reveal the negative side of online communication that can have an impact on low subjective wellbeing. The usage of excessive and uncontrolled online communication will cause internet addiction, compulsive use, and mistreatment (Akin and Iskender (2011); Lee-Won et al. (2015); 
Wohn and LaRose (2014)), which in turn has a negative effect on subjective well-being. Besides other impacts, one of the characteristics in online communication is that it allows users to publish or update profile photos/stats to public updates so that it can be seen by others, this may have different and opposite effects on one's subjective well-being (Maddux, 2018). A study exposed that a person could penetrate one's own profile and have an impact on declining self-esteem (Toma, 2013).

Based on the relationship between these variables, the hypothesis of this study is there is a significant effect between the quality of online communication and subjective well-being among entrepreneurs in urban areas.

\section{METHODS}

\subsection{Procedure and participants}

This study first applied for permission to use the online communication quality scale and the results of the adaptation of the subjective well-being scale. Then this research conducted a literature study and compiled a research questionnaire through the help of Google forms. Furthermore, the pilot study was given to 30 participants who had the same criteria as the study participants. After the measuring instrument is ready to use, this research spreads the questionnaire link to several acquaintances of entrepreneurs and various social media. The sample collection uses the incidental sampling technique.

The sample of this research is 85 people who meet the criteria of working in Jakarta, having a dam business unit aged $20-40$ years. Table 1 shows participant demographic data. The majority of participants were women (53\%), aged 20-25 years (50\%), had a bachelor's degree (78\%), were married (75\%), and had started doing business around 1-3 years (39\%).

\subsection{Measurement and model analysis}

The independent variable of this study is the quality of online communication, which is defined as the existence of effective communication between individuals that occurs via the internet and uses applications such as email, instant messaging, social networking sites. Collecting data of this variable uses a questionnaire of the quality of online communication that has been compiled by Syam (2017). This scale was arranged based on five general qualities of interpersonal communication by DeVito (2010), namely openness, empathy, supportiveness, positiveness, and equality. This scale uses a Likert scale with 5 alternative answers, has 27 items that have been declared valid based on the validity test, as well as the alpha value of 0.82 .

The dependent variable of this study is subjective well-being. This variable data collection uses a scale of subjective wellbeing by Diener et al. (2009) which has been adapted by Hutomo (2017). This scale is divided into satisfaction with life scale, SPANE (Scale of Positive and Negative Experience), and flourishing scale. After carrying out a series of adaptation processes, the total items become 33 with 3 invalid items at each scale. The value of Cronbach's alpha is 0.74 . The use of the scale is believed to have high consistency and reliability values. Referring to previous studies that the scale has passed the parametric
Table 1: Demographic Data

\begin{tabular}{lcc}
\hline Variable & Frequency & Percentage \\
\hline Gender & & \\
- Male & 45 & 53 \\
- Female & 40 & 47 \\
Status & & \\
- Single & 21 & 25 \\
- Married & 64 & 75 \\
Age & & \\
- 20-25th years old & 42 & 50 \\
- 26-30th years old & 20 & 23 \\
- 31-35 years old & 12 & 14 \\
- 36-40th years old & 11 & 13 \\
Education & & \\
- High School & 11 & 13 \\
- Bachelor's degree & 66 & 78 \\
- Master's degree & 7 & 8 \\
- Doctoral's degree & 1 & 1 \\
Time to do business & & \\
- <1st year & 26 & 31 \\
- 1st - 3rd years & 33 & 39 \\
- 4th - 6th years & 7 & 8 \\
- 7th - 9th years & 11 & 13 \\
- > 10th years & 8 & 9 \\
\hline
\end{tabular}

test stage in several countries and has been translated into many languages.

This study uses descriptive data analysis and linear regression. This research is also cross-sectional because it is only done at one particular time.

\section{RESULT AND DISCUSSION}

\subsection{Result}

Descriptive data analysis is used to get the description of both variable online communication quality and subjective wellbeing among entrepreneurs in DKI Jakarta. The descriptive statistics of the two scales are shown in Table 2.

Then a standard score is made using the following formula:

$$
(\text { Mean }-1 S D) \leq X_{i} \leq(\text { Mean }+1 S D)
$$

Based on this formula, the scale can be categorized into three categories: high, medium, and low.

Based on the standard score categorization, we get the illustration of online communication quality and subjective wellbeing being shown on the Figure 1.

Based on Table 3, Figure 1 and Figure 2, most of the samples have medium quality online communication with 61 participants (72\%), with the remaining 10 participants (12\%) in the low category and 14 participants $(16 \%)$ with the high-quality online communication category. In the subjective well-being variable, the highest number of samples was in the medium category with 62 people (73\%), the next highest was in the high 
Table 2: The descriptive statistics

\begin{tabular}{lccccccc}
\hline \multicolumn{8}{c}{ Table 2: The descriptive statistics } \\
& $\mathrm{N}$ & Range & Minimum & Maximum & Mean & $\begin{array}{l}\text { Std. De- } \\
\text { viation }\end{array}$ & Variance \\
\hline $\begin{array}{l}\text { Online communica- } \\
\text { tion quality }\end{array}$ & 85 & 73 & 57 & 130 & 98.75 & 10.671 & 113.879 \\
$\begin{array}{l}\text { Subjective Well- } \\
\text { being }\end{array}$ & 85 & 81 & 32 & 113 & 85.76 & 14.106 & 198.968 \\
Valid N (listwise) & 85 & & & & & & \\
\hline
\end{tabular}

Table 3: Standard Score Categorization

\begin{tabular}{lll}
\hline \multirow{2}{*}{ Category } & $\begin{array}{l}\text { Standard Score } \\
\text { of Online Com- } \\
\text { munication } \\
\text { Quality }\end{array}$ & $\begin{array}{l}\text { Standard Score } \\
\text { of subjective } \\
\text { well-being }\end{array}$ \\
\hline Low & $\geq 109$ & $\geq 100$ \\
Medium & $89-108$ & $70-99$ \\
High & $\leq 88$ & $\leq 71$ \\
\hline
\end{tabular}

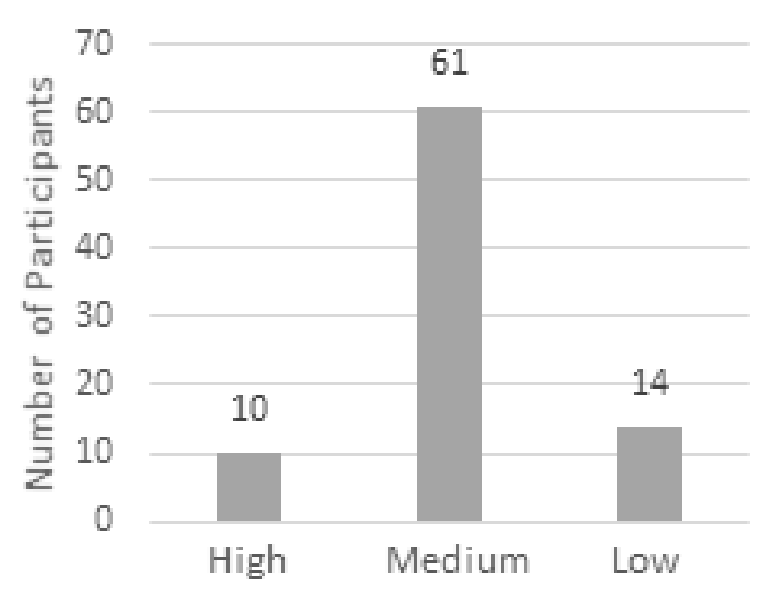

Figure 1: Profile of online communication quality

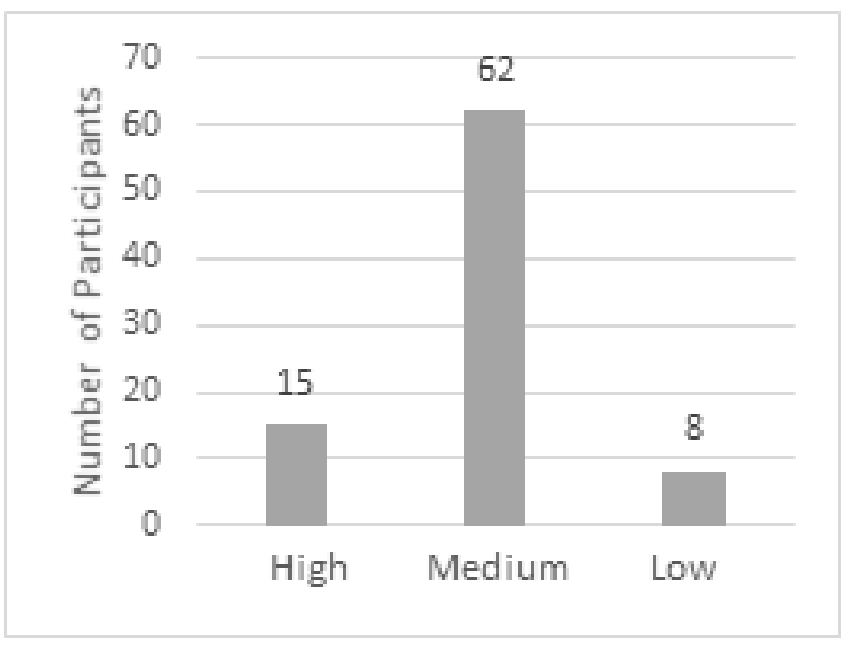

Figure 2: Profile of Subjective Well-Being category with $15(18 \%)$, and the rest in the low category was 8 people $(9 \%)$.

Furthermore, additional data obtained from this study relates to online communication that is the application that is often used and the perceived benefits after online communication. The results are illustrated in the Table 4.

Table 4: Additional data on online communication quality

\begin{tabular}{|c|c|c|c|}
\hline & & Frequency & Percentage \\
\hline \multicolumn{4}{|c|}{$\begin{array}{l}\text { Program Applica- } \\
\text { tions }\end{array}$} \\
\hline Whatsapp & & 85 & $100 \%$ \\
\hline Telegram & & 39 & $46 \%$ \\
\hline Line & & 63 & $74 \%$ \\
\hline $\begin{array}{l}\text { Blacberry } \\
\text { ger }\end{array}$ & Messen- & 56 & $66 \%$ \\
\hline \multicolumn{3}{|l|}{ ger } & $64 \%$ \\
\hline Twitter & & 40 & $47 \%$ \\
\hline Instagram & & 60 & $71 \%$ \\
\hline Email & & 62 & $73 \%$ \\
\hline Lain-lain & & 4 & $5 \%$ \\
\hline \multicolumn{4}{|c|}{ The Benefits } \\
\hline Effective & & 15 & $18 \%$ \\
\hline efficient & & 28 & $33 \%$ \\
\hline Cheap & & 14 & $16 \%$ \\
\hline Easier & & 28 & $33 \%$ \\
\hline Move clos & & 14 & $16 \%$ \\
\hline Informativ & & 5 & $6 \%$ \\
\hline $\begin{array}{l}\text { Communic } \\
\text { without lin }\end{array}$ & $\begin{array}{l}\text { ation } \\
\text { hits }\end{array}$ & 9 & $11 \%$ \\
\hline Others & & 5 & $6 \%$ \\
\hline
\end{tabular}

Analysis of the data in this study uses simple linear regression analysis techniques to see the causality relationship between variables. Previously we conducted assumption tests to find out the normality and linearity of the data. Assumption tests are carried out to ensure there are no errors in the data collection process. The results of normality and linearity tests can be seen in the Table 5 .

Based on the Table 6, the significant value for the online communication quality variable is 0.390 and subjective wellbeing is 0.257 . Both have significant values more than 0.05, which indicates that the data is normally distributed. 
Table 5: Result of Normality Test

\begin{tabular}{lcccc}
\hline Variable & $\begin{array}{l}\text { K- } \\
\text { SZ }\end{array}$ & $\begin{array}{l}\text { Asymmp. } \\
\text { Sig (P) }\end{array}$ & Alpha () & Result \\
\hline $\begin{array}{l}\text { Online com- } \\
\text { munication }\end{array}$ & 0.902 & 0.39 & 0.05 & Normal \\
$\begin{array}{l}\text { quality } \\
\text { Subjective }\end{array}$ & 1.013 & 0.257 & 0.05 & Normal \\
Well-being & & & & \\
\hline
\end{tabular}

Table 6: Result of Linearity Test

\begin{tabular}{lcccc}
\hline Variable & df & F & Sig.Linearity & Result \\
\hline $\begin{array}{l}\text { Online commu- } \\
\text { nication quality }\end{array}$ & 1 & 16.6 & 0 & Linear \\
$\begin{array}{l}\text { Subjective Well- } \\
\text { being }\end{array}$ & & & & \\
\hline
\end{tabular}

Table 6 shows that there is a linear relationship between the quality of online communication and subjective well-being. In additions, there is a significant influence between the quality of online communication and subjective well-being. It also can be seen through the significance test through the Table 7.

Table 7 shows the significance test for simple linear regression. It can be concluded that there is a significant influence between the quality of online communication and subjective well-being for entrepreneurs in DKI Jakarta. This is seen from the significant level of $\mathrm{P}=0.016$ which means the value of sig. (p) $<0.05$. Based on these results it can be said that the regression model can be used to predict the dependent variable. In addition, the Table obtained a constant value of 32,474 and a regression coefficient of $\mathrm{X}$ of 0.540 . This means that for every addition of 1 value of online communication quality, the value of subjective well-being increases by 0.540 . The regression equation is as follows: $Y=32.474+0.540 X$.

Table 8 shows that the value of $\mathrm{R}$ is a correlation coefficient, which is equal to 0.408 which means that the relationship between the research variables is in the quite strong category. Through this Table also obtained the value of $\mathrm{R}$ Square or the coefficient of determination that shows how well the regression model is formed by the interaction of independent variables and dependent variables. The value of $\mathrm{R}$ Square $\left(R^{2}\right)$ obtained is $0.167(16.7 \%)$. This value means that the contribution of online communication quality to subjective well-being is $16.7 \%$ and the other $83.3 \%$ is influenced by other variables.

\subsection{Discussion}

The results of this study indicate the influence of online communication quality on subjective well-being with a significant level of $\mathrm{P}=0.016$ which means the value of sig $(\mathrm{p})<0.05$ and the influence/contribution of $16.7 \%$ and the other $83.3 \%$ are influenced by other variables. This research basically reveals how cyberspace can have an impact on one's subjective well-being or subjective well-being. There are several explanations, theories, and research results related to this study which will be explained as follows.

Maddux (2018) explains that "a good life" is a life in which there are more pleasure and happiness than pain and suffering. Individual morals, values, virtues, goals, achievements, and contributions to others and society are largely irrelevant. The important thing is the extent to which a person enjoys life, generally feels good, experiences pleasure, and gets life satisfaction. In this conception, the individual is the sole judge of the happiness and satisfaction of his life. This concept explains that a person's choice to use effective online communication is because through this medium he has enjoyed his life and experienced the pleasure of using it. This is evidenced by additional data from this study which found that the benefits gained in online communication were to make communication more effective and efficient.

One of the strongest personality trait predictors of subjective well-being is extraversion (Gale et al. (2013); Gomez et al. (2012); Maddux (2018)). Because people with this personality have more social interaction and are responsive to the environment, so they have lots of friends, are friendly, sociable, and need other people to communicate with. Therefore, they will use any media to keep communicating with others including online media. Some research also shows a significant relationship between personality extraversion and online communication (via internet / social media) (Gosling et al., 2011).

This research shows one of the things that makes a high level of online communication is the existence of extraversion personality which in the end has an impact on one's subjective well-being. In addition, people with high extraversion personalities will be able to manage their emotions (both positive and negative) so that they can establish good virtual relationships. They can express their emotions through words, emoticons, images, and videos in the application, and are able to overcome the unpleasant treatment in the virtual world. Gosling et al. (2011) also found that people with extraversion personalities would expand their online network of friends into the online domain.

How online communication can affect someone's subjective well-being is also formed through a collective culture (Diener et al. (2009); Lopez and Snyder (2012). In this case, a person's happiness is determined by the presence of other people in his life or activities will be more meaningful if done together. One theory related to this is the social presence theory which was first introduced by Short et al. (1976) which explains that individuals view others as real people, and any interaction between them is considered as a relationship (Wood and Smith, 2005). Social presence theory shows that different media convey different degrees of presence from the substance perceived to an interaction. Connection rates are based on the amount of nonverbal information available to recipients through certain channels. Thus, a person may feel a certain level of social presence when communicating online with others. Online communication is done to fulfill certain needs that cannot be done directly. One might find warmth and happiness in the glow on a cell phone/computer screen.

The number of friends in online communication also determines user welfare. One possible explanation for the positive relationship between social network size and user well-being 
Table 7: Result of Linear Regression Test

\begin{tabular}{|c|c|c|c|c|c|}
\hline \multirow[t]{2}{*}{ Variabel } & \multicolumn{2}{|c|}{$\begin{array}{l}\text { Unstandardized } \\
\text { Coefficients }\end{array}$} & \multirow[t]{2}{*}{ Alpha () } & \multirow[t]{2}{*}{ Sig. (P) } & \multirow[t]{2}{*}{ Result } \\
\hline & B & $\begin{array}{l}\text { Std. Er- } \\
\text { ror }\end{array}$ & & & \\
\hline $\begin{array}{l}\text { Online commu- } \\
\text { nication quality }\end{array}$ & 32.474 & 13.155 & 0.05 & 0.016 & Significant \\
\hline $\begin{array}{l}\text { Subjective Well- } \\
\text { being }\end{array}$ & 0.54 & 0.132 & & & \\
\hline
\end{tabular}

Table 8: The amount of influence between variables

\begin{tabular}{|c|c|c|c|c|}
\hline Variable & Sig. & $\mathrm{R}$ & & $\begin{array}{l}\text { Square } \\
\left(R^{2}\right)\end{array}$ \\
\hline $\begin{array}{l}\text { Online commu- } \\
\text { nication quality } \\
\text { Subjective Well- } \\
\text { being }\end{array}$ & 0 & 0.408 & & 0 \\
\hline
\end{tabular}

is that users feel a greater amount of social support when their network size (Manago et al., 2012). Happiness can increase from social networking because it provides an affirmation of their self-esteem (eg, "I am a valuable person because I have many friends") (Kim and Lee, 2011). A study revealed that the more time spent using online communication on social media, a person will feel a strong connection emotionally. In contrast to individuals who have little interaction on social media, where they merely exchange information does not involve emotional relations (Ellison et al., 2007). In addition, Kim and Lee (2011) also examined the non-linear relationship between the size of social networks and social support perceived by users. Users with too few friends will receive very limited social support, but users with too many friends will not have enough time and effort to maintain a quality relationship with them too.

Life circumstance theories propose that SWB is the result of a number of positive and negative living conditions of a person both daily life experiences (large and small) and demographic factors that are liked or disliked such as socioeconomic status, education, and physical health (Lyubomirsky (2013); Maddux (2018)), this can explain why the role of online communication only gives $16.7 \%$ of subjective well-being and $83.3 \%$ is influenced by other variables Diener et al. (1997) and Wheatley (2017) mention factors that can influence subjective well-being, besides technology, they are subjective satisfaction, income, demographic factors (age, gender, race/ethnicity, occupation and education, religion, and marriage and family), behavior and outcomes, that is social contact, a series of life events and activities, and personality, health, and time management.

\section{CONCLUSION}

Online communication does not necessarily eliminate people from their offline world but may indeed be used to sup- port relationships and keep people in contact, even when life changes keep them away from each other. The results of this study confirm that online communication quality influence the subjective well-being.

\section{References}

Akin, A., Iskender, M., 2011. Internet addiction and depression, anxiety and stress. International Online Journal of Educational Sciences 3 (1), 138-148.

Akram, W., Kumar, R., 2017. A study on positive and negative effects of social media on society. International Journal of Computer Sciences and Engineering 5 (10), 351-354.

URL: https://doi.org/10.26438/ijcse/v5i10.351354

Allameh, S. M., Momeni, Z., Esfahani, Z. S., Bardeh, M. K., 2011. An assessment of the effect of information communication technology on human resource productivity of mobarekeh steel complex in isfahan (iran). Procedia Computer Science 3, 1321-1326.

URL: https : //doi.org/10.1016/j.procs. 2011.01.010

Bae, S.-M., 2019. The relationship between smartphone use for communication, social capital, and subjective well-being in korean adolescents: Verification using multiple latent growth modeling. Children and Youth Services Review 96, 93-99.

URL: https://doi.org/10.1016/j.childyouth.2018.11.032

Bucăţa, G., Rizescu, A. M., 2017. The role of communication in enhancing work effectiveness of an organization. Land Forces Academy Review 22 (1), 49-57.

URL: https : //doi .org/10.1515/raft-2017-0008

Daukantaitè, D., Zukauskiene, R., 2012. Optimism and subjective well-being: Affectivity plays a secondary role in the relationship between optimism and global life satisfaction in the middle-aged women: Longitudinal and crosscultural findings. Journal of Happiness Studies 13 (1), 1-16.

URL: https : //doi .org/10.1007/s10902-010-9246-2

de Wet, W., Koekemoer, E., Nel, J., 2016. Exploring the impact of information and communication technology on employees' work and personal lives. SA Journal of Industrial Psychology 42 (1), 11.

URL: https://sajip.co.za/index.php/sajip/article/view/ 1330

DOI: $10.4102 /$ sajip.v42i1. 1330

DeVito, J. A., 2010. Komunikasi Antarmanusia. Karisma Publishing.

DeVito, J. A., 2013. The Interpersonal Communication Book 13th ed. (13th ed.). Pearson Education.

Diener, E., Suh, E., Oishi, S., 1997. Recent findings on subjective well-being. Indian Journal of Clinical Psychology 24 (1), 25-41.

Diener, E., Wirtz, D., Tov, W., Kim-Prieto, C., Choi, D., Oishi, S., BiswasDiener, R., 2009. New measures of well-being: Flourishing and Positive and Negative Feelings (Ed Diener (ed.); Vol. 39). Springer, Netherlands. URL: https : //doi .org/10.1007/978-90-481-2354-4 DOI: $10.1007 / 978-90-481-2354-4$

Efendi, R., 2020. Pentingnya memperkuat umkm dalam menghadapi pandemi corona covid-19.

URL: https : //www. liputan6.com/regional/read/4252808/ pentingnya-memperkuat-umkm-dalam-menghadapi-pandemi-corona

Ellison, N. B., Steinfield, C., Lampe, C., 2007. The benefits of facebook "friends:" social capital and college students' use of online social network 
sites. Journal of Computer-Mediated Communication 12 (4), 1143-1168. URL: https ://doi.org/10.1111/j.1083-6101.2007.00367.x

Gale, C. R., Booth, T., Mōttus, R., Kuh, D., Deary, I. J., 2013. Neuroticism and extraversion in youth predict mental wellbeing and life satisfaction 40 years later. Journal of Research in Personality 47 (6), 687-697. URL: https : //doi.org/10.1016/j.jrp.2013.06.005

Gomez, V., Allemand, M., Grob, A., 2012. Neuroticism, extraversion, goals, and subjective well-being: Exploring the relations in young, middle-aged, and older adults. Journal of Research in Personality 46 (3), 317-325. URL: https://doi.org/10.1016/j.jrp.2012.03.001

Gosling, S. D., Augustine, A. A., Vazire, S., Holtzman, N., Gaddis, S., 2011. Manifestations of personality in online social networks: Self-reported facebook-related behaviors and observable profile information. Cyberpsychology, Behavior, and Social Networking 14 (9), 483-488.

URL: https ://doi.org/10.1089/cyber.2010.0087

Grieve, R., Indian, M., Witteveen, K., Tolan], G. A., Marrington, J., 2013. Face-to-face or facebook: Can social connectedness be derived online?Computers in Human Behavior 29 (3), $604-609$.

URL: http://www.sciencedirect.com/science/article/pii/ S0747563212003226

DOI: https://doi.org/10.1016/j.chb.2012.11.017

Hurlock, E., 1994. Psikologi Perkembangan: Suatu Pendekatan Sepanjang Rentang Kehidupan. Erlangga.

Hutomo, P., 2017. Hubungan Dukungan Sosial dan Subjective Well-being pada pegawai negeri sipil (PNS) yang memasuki masa pension (MPP) Kota Makassar. Universitas Hasanuddin.

Ishii, K., 2017. Online communication with strong ties and subjective wellbeing in japan. Computers in Human Behavior 66, 129-137. URL: https : //doi.org/10.1016/j.chb.2016.09.033

Kim, J., Lee, J.-E. R., 2011. The facebook paths to happiness: Effects of the number of facebook friends and self-presentation on subjective well-being. Cyberpsychology, Behavior, and Social Networking 14 (6), 359-364. URL: https : //doi .org/10.1089/cyber. 2010.0374

Lee-Won, R. J., Herzog, L., Park, S. G., 2015. Hooked on facebook: The role of social anxiety and need for social assurance in problematic use of facebook. Cyberpsychology, Behavior, and Social Networking 18 (10), 567-574. URL: https : //doi .org/10.1089/cyber. 2015.0002

Lestari, R., 2018. Media Sosial Memicu Kesepian pada Generasi Milenial. URL: http://m.metrotvnews.com/read/2018/06/11/887084/ media-sosial-memicu-kesepian-pada-generasi-milenial

Li, C., Shi, X., Dang, J., 2014. Online communication and subjective wellbeing in chinese college students: The mediating role of shyness and social self-efficacy. Computers in Human Behavior 34, 89-95.

URL: https : //doi.org/10.1016/j.chb.2014.01.032

Lopez, S. J., Snyder, C., 09 2012. The Oxford Handbook of Positive Psychology. Oxford University Press.

Lyubomirsky, S., 2013. The Myths of Happiness: What Should Make You Happy, but Doesn't, What Shouldn't Make You Happy, but Does. Penguin Publisher.

Maddux, J. E., 2018. Subjective Well-Being and Life Satisfaction. Routledge.

Manago, A. M., Taylor, T., Greenfield, P. M., 2012. Me and my 400 friends: The anatomy of college students' facebook networks, their communication patterns, and well-being. Developmental Psychology 48 (2), 369-380. URL: https://doi.org/10.1037/a0026338

Mashabi, S., 2020. Daftar 18 Daerah yang Terapkan PSBB dari Jakarta hingga Makassar.

URL: https://nasional .kompas . com/read/2020/04/20/ 05534481/daftar-18-daerah-yang-terapkan-psbb-dari-jakarta

Mustaqim, A., 2016. Media Sosial Sarang Eksploitasi Anak. URL: http://jateng.metrotvnews.com/peristiwa/ zNAGAe8k-media-sosial-sarang-eksploitasi-seksual-anak

Nixon, C., 2014. Current perspectives: the impact of cyberbullying on adoles- cent health. Adolescent Health, Medicine and Therapeutics 5, 143-158. URL: https : //doi.org/10.2147/AHMT.S36456

Park, J., Lee, D. S., Shablack, H., Verduyn, P., Deldin, P., Ybarra, O., Jonides, J., Kross, E., 2016. When perceptions defy reality: The relationships between depression and actual and perceived facebook social support. Journal of Affective Disorders 200, 37-44.

URL: https ://doi.org/10.1016/j.jad.2016.01.048

Peraturan Pemerintah, 2020. PP No. 21 Tahun 2020 tentang Pembatasan Sosial Berskala Besar- PSBB.

URL: https://jdih.setkab.go.id/PUUdoc/176085/PP_Nomor_21_ Tahun_2020.pdf

Purba, F., Fitriana, T., 2019. Sociodemographic determinants of self-reporting mental health problems in Indonesian urban population. Psychological Research on Urban Society 2 (1), 59-64.

URL: http://proust.ui.ac.id/index.php/journal/article/ view/46

DOI: $10.7454 /$ proust.v2i 1.46

Rainie, L., Anderson, J., 2018. Stories From Experts About the Impact of Digital Life.

URL: http: //www pewinternet.org/2018/07/03/

stories-from-experts-about-the-impact-of-digital-life/

Sampasa-Kanyinga, H., Lewis, R. F., 2015. Frequent use of social networking sites is associated with poor psychological functioning among children and adolescents. Cyberpsychology, Behavior, and Social Networking 18 (7), 380-385.

URL: https://doi.org/10.1089/cyber.2015.0055

Short, J., Williams, E., Christie, B., 1976. The social psychology of telecommunications. Wiley.

Smith, A., 2018. Declining Majority of Online Adults Say the Internet Has Been Good for Society.

URL: http: //www . pewinternet .org/2018/04/30/declining-

majority-of-online-adults-say-the-internet-has-been-good

Syam, U., 2017. Hubungan antara Kualitas Komunikasi Online dengan Persepsi Tentang Kualitas Hubungan Persahabatan pada Remaja SMP di Makassar. Universitas Hasanuddin.

Toma, C. L., 2013. Feeling better but doing worse: Effects of facebook selfpresentation on implicit self-esteem and cognitive task performance. Media Psychology 16 (2), 199-220. URL: https ://doi.org/10.1080/15213269.2012.762189

Valkenburg, P. M., Peter, J., 2007. Preadolescents' and adolescents' online communication and their closeness to friends. Developmental Psychology 43 (2), 267-277.

URL: https : //doi.org/10.1037/0012-1649.43.2.267

Varnali, K., 2010. The impact of the internet on marketing strategy. International Journal of E-Business Research 6 (4), 38-51.

URL: https ://doi .org/10.4018/jebr. 2010100104

Wheatley, D., 2017. Time Well Spent Subjective Well- Being and the Organization of Time. Rowman Littlefield International Ltd.

Wohn, D. Y., LaRose, R., 2014. Effects of loneliness and differential usage of facebook on college adjustment of first-year students. Computers Education $76,158-167$.

URL: https : //doi .org/10.1016/j.compedu. 2014.03.018

Wood, A. F., Smith, M. J., 2005. Online Communication: Linking Technology, Identity, And Culture (2nd ed.). Lawrence Erlbaum Associates Publishers.

Wright, K. B., Rosenberg, J., Egbert, N., Ploeger, N. A., Bernard, D. R., King, S., 2013. Communication competence, social support, and depression among college students: A model of facebook and face-to-face support network influence. Journal of Health Communication 18 (1), 41-57. URL: https : //doi .org/10.1080/10810730.2012.688250

Zebua, F., 2017. Laporan dailysocial: Survey instant messaging. URL: https: //dailysocial .id/post/laporan-dailysocialsurvey-instant-messaging-2017 